\title{
PERANCANGAN MEDIA PEMBELAJARAN FISIKA MATERI KONSEP TERMODINAMIKA DALAM MESIN KALOR DAN SIFAT-SIFAT GAS IDEAL MONOATOMIK UNTUK SMA KELAS XI IPA
}

\author{
Hotmian Sitohang \\ Teknik Informatika, STMIK Palangkaraya \\ Jl. G. Obos No. 114 Palangkaraya-Kalimantan Tengah \\ Email: hotmiansitohang@gmail.com
}

\begin{abstract}
Computer-based learning system is now much improved, making the faculty more enthusiastic in making a model of learning so that students do not get bored easily. Physics is a subject that is grealty feared by students because the course is filled by counting, concepts and formulas. designing or creating instructional media. Learning physics is expected to be an interactive learning tool that can improve the learning interest of the user. This study uses $\mathrm{R} \&$ D (Research and Development), namely the development of computer-based animation instructional media. Making learning applications of thermodynamics in physics to the concept of heat engines and properties of monatomic ideal gas is by using Visual Basic 6.0 software to design the application, Microsoft Access 2007 to design a database system for data storage applications, while Adobe Photoshop to design the image.

The test results showed that the instructional media program for the display program, the suitability of the program with the teaching material, and technical quality were good. Based on these results it can be concluded that the program deserves to be a medium of learning and can be used in teaching Physics especially about heat engines and thermodynamic properties of monatomic ideal gas to high school grade XI.
\end{abstract}

Keywords: Media Education, Physics, Thermodynamics in Engineering Heat, Ideal Gas properties of monatomic 


\section{PENDAHULUAN}

Dunia pendidikan dewasa ini telah menunjukan kemajuan yang sangat pesat seiring dengan kemajuan ilmu pengetahuan dan teknologi. Perkembangan tersebut menuntut adanya usaha persiapan peserta didik agar dapat turut serta dalam upaya pengembangan ilmu pengetahuan dan teknologi bagi generasi berikutnya. Kemampuan untuk memanfaatkan teknologi dalam upaya perkembangan pendidikan tentu sangat banyak tergantung pada jumlah dan kemampuan para ahli dalam bidang pendidikan.

Sementara itu, teknologi komunikasi yang modern telah merubah wajah dunia, salah satunya dengan adanya inovasi teknologi komunikasi pendidikan dalam bentuk pendayagunaan media pembelajaran.

Fisika adalah salah satu ilmu dalam bidang sains yang biasanya dipelajari melalui pendekatan secara matematis sehingga seringkali ditakuti dan cenderung tidak disukai siswa karena pada umumnya siswa yang memiliki kecerdasan Logical Mathematical sajalah yang menikmati fisika. Belajar fisika bukan hanya sekedar tahu matematika, tetapi lebih jauh anak didik diharapkan mampu memahami konsep yang terkandung di dalamnya, menuliskannya ke dalam parameter-parameter atau simbolsimbol, memahami permasalahan serta menyelesaikannya secara matematis. Tidak jarang hal inilah yang menyebabkan ketidak senangan anak didik terhadap mata pelajaran ini menjadi semakin besar dan peserta didik merasa kesulitan untuk menalarnya. Oleh sebab itu prestasi belajar siswa di sekolah menurun karena masih banyak siswa melakukan kesalahan yang berkaitan dengan pengertian, konsep-konsep, dan keterampilan matematika mengenai fisika termasuk konsep termodinamika dan sifat-sifat gas ideal.

Dalam kurikulum berbasis kompetensi, salah satu kompetensi guru yang harus ditingkatkan adalah kemampuan dalam menggunakan media pembelajaran. Guru dapat mempelajari berbagai software untuk membuat media pembelajaran yang disesuaikan dengan kebutuhan para siswanya. Salah satu software yang dapat membuat berbagai media seperti video, gambar, suara, dan sebagainya 
dengan cara yang mudah adalah Visual

Basic 6.0 dan database Access 2007 untuk menyimpan data.

\section{PEMBAHASAN}

Media Pembelajaran

Menurut kamus besar bahasa indonesia, media berarti perantara atau penghubung yang terletak di antara dua pihak. Banyak batasan yang diberikan tentang media. AECT (Association of Educational and Communication Technology) di Amerika, membatasi media sebagai segala bentuk dan saluran yang digunakan orang untuk menyampaikan pesan/informasi.

Dari pendapat di atas dapat ditarik kesimpulan bahwa media pembelajaran adalah segala sesuatu yang dipergunakan untuk menyalurkan pesan serta dapat merangsang pikiran, perasaan, perhatian dan kemauan siswa sehingga dapat mendorong terjadinya proses belajar yang disengaja, bertujuan dan terkendali.

Ada beberapa keuntungan bila media digunakan dalam proses pembelajaran, yaitu adanya tutor sebaya dalam kelas, yang kadangkadang lebih mudah menerangkan temuan dan pemahamannya kepada temannya. Selain itu, kerjasama yang terjadi dalam penggunaan media akan membuat suasana lebih menyenangkan.

Visual Basic 6.0

Basic adalah salah suatu developement tools untuk membangun aplikasi dalam lingkungan Windows. Dalam pengembangan aplikasi, Visual Basic menggunakan pendekatan Visual untuk merancang user interface dalam bentuk form, sedangkan untuk kodingnya menggunakan dialek bahasa Basic yang cenderung mudah dipelajari. Visual Basic telah menjadi tools yang terkenal bagi para pemula maupun para developer. Visual Basic adalah bahasa pemrograman berbasis Microsoft Windows yang merupakan Object Oriented Programming (OOP), yaitu pemrograman berorientasi objek, Visual Basic menyediakan objek-objek yang sangat kuat, berguna dan mudah.

Model Waterfall

$\begin{array}{ccc}\text { Pada } & \text { penelitian ini } \\ \text { pengembangan } & \text { perangkat lunak }\end{array}$ menggunakan model Waterfall yang bersifat sekuensial dan terdiri dari 5 tahap yang saling terkait dan 
mempengaruhi. Model Waterfall dapat terlihat pada Gambar 1.

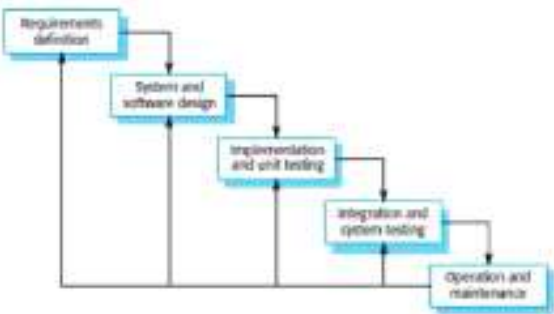

Gambar 1. Model Waterfall (sumber: sommerville, 2007)

Aktivitas-aktivitas yang terdapat dalam model waterfall adalah sebagai

berikut:

\section{Requirement definition}

Pada tahap ini dilakukan pengumpulan kebutuhan elemen sistem. Proses pengumpulan kebutuhan diintensifkan ke sistem.

2. System and software design

Pada tahap ini akan mengubah kebutuhan-kebutuhan menjadi bentuk karakteristik yang dimengerti oleh sistem sebelum dilakukan penulisan program.

\section{Implementation and testing}

Pada tahap ini adalah tahap yang termasuk dalam penulisan kode program yang merupakan tahap penerjemahan desain sistem yang telah dibuat ke dalam bentuk perintah-perintah yang dimengerti komputer dengan mempergunakan bahasa pemrograman, middleware dan basis data tertentu di atas platform yang menjadi standar. Berbeda dengan 2 tahap sebelumnya, pada tahap penulisan kode program ini keterlibatan pengguna tidaklah terlalu besar.

4. Integration and system testing

Pengujian sistem dilakukan untuk memastikan bahwa sistem yang dibuat telah sesuai dengan desainnya dan semua fungsi dapat dipergunakan dengan baik tanpa ada kesalahan. Pengujian perangkat sistem biasanya dilakukan dalam 2 tahap yang saling independen, yaitu: pengujian oleh internal pembuat dan pengujian oleh pengguna dari sistem.

\section{Operation and maintenance.}

Penerapan program merupakan tahap dimana pengguna menerapkan atau menggunakan sistem yang telah selesai dibuat dan diuji ke dalam lingkungannya dan juga dapat melakukan pemeliharaan, seperti penyesuaian atau perubahan karena adaptasi dengan situasi sebenarnya. 


\section{MATERI PELAJARAN}

Fisika adalah ilmu yang mempelajari gejala alam dengan mengumpulkan dan mencari hubungan di antaranya untuk memperoleh manfaat. Pemahaman Fisika ditujukan kepada kemampuan siswa untuk memahami hukum-hukum Fisika. Penerapan Fisika dalam kehidupan sehari-hari, penerapan fisika dalam teknologi, pengembangan Fisika dan pengembangan kemampuan diri dalam bidang keahlian khusus.

Termodinamika dalam Mesin Kalor

Termodinamika dalam bahasa Yunani adalah thermos yang artinya panas, sedangkan dynamic artinya perubahan. Jadi termodinamika adalah fisika energi, panas, kerja, entropi dan kespontanan proses. Termodinamika berhubungan dekat dengan mekanika statistik di mana banyak hubungan termodinamika berasal. Pada sistem di mana terjadi proses perubahan wujud atau pertukaran energi, termodinamika klasik tidak berhubungan dengan kinetika reaksi (kecepatan suatu proses reaksi berlangsung). Karena alasan ini, penggunaan istilah "termodinamika" biasanya merujuk pada termodinamika setimbang. Dengan hubungan ini, konsep utama dalam termodinamika adalah proses kuasistatik, yang diidealkan, proses "super pelan". Proses termodinamika bergantungwaktu dipelajari dalam termodinamika tak-setimbang. Karena termodinamika tidak berhubungan dengan konsep waktu, telah diusulkan bahwa termodinamika setimbang seharusnya dinamakan termostatik.

Sifat-sifat Gas Ideal Monoatomik

Gas yang paling sederhana dan mendekati sifat-sifat gas sejati adalah gas ideal. Adapun sifat-sifat gas ideal diantaranya adalah sebagai berikut:

1. Gas terdiri dari molekul-molekul yang sangat banyak, dengan jarak pisah antar molekul lebih besar dari ukuran molekul. Hal ini meunjukkan bahwa gaya tarik antar molekul sangat kecil dan diabaikan.

2. Molekul-molekul gas bergerak acak ke segala arah sama banyaknya dan memenuhi hukum Newton tentang gerak.

3. Molekul-molekul gas hanya bertumbukan dengan dinding tempat gas secara sempurna.Dinding wadah adalah 
4. kaku sempurna dan tidak akan bergerak.

Persamaan umum gas ideal dapat dituliskan:

\section{$\mathbf{P V}=\mathbf{n R T}$}

Keterangan:

$\mathrm{P}=$ tekanan gas $\left(\mathrm{N} / \mathrm{m}^{2}=\mathrm{P}_{\mathrm{a}}\right)$

$\mathrm{V}=$ volume gas $\left(\mathrm{m}^{3}\right)$

$\mathrm{N}=$ jumlah mol gas (mol)

$\mathrm{T}=$ suhu gas $(\mathrm{K})$

$\mathrm{R}=$ tetapan umum gas $=8,314$

$\mathrm{J} / \mathrm{mol} \mathrm{K}$

Persamaan umum gas ideal

tersebut di atas dapat juga dinyatakan dalam bentuk:

$\mathrm{n}=\mathrm{N} / \mathrm{NA}$

$\mathrm{PV}=\mathrm{nRT}$

$\mathrm{PV}=\mathrm{NRT} / \mathrm{NA}$ dengan $\mathrm{R} / \mathrm{NA}=\mathrm{k}$

Maka diperoleh:

$$
\begin{aligned}
\mathrm{PV} & =\mathrm{NkT} \\
\mathrm{k} & =\text { tetapan Boltzman } \\
& =1,38 \cdot 10^{-23} \mathrm{~J} / \mathrm{k} .
\end{aligned}
$$

\section{METODE}

Jenis penelitian ini termasuk penelitian pengembangan atau yang disebut dengan metode $R \& D$ (Research and Development), yaitu pengembangan media pembelajaran berbasis animasi komputer. Penelitian pengembangan adalah suatu proses atau langkah-langkah untuk mengembangkan suatu produk yang telah ada (sugiono, 2009). Produk yang dihasilkan dalam penelitan ini berupa media pembelajaran fisika yaitu pokok bahasan konsep termodinamika dalam mesin kalor dan sifat-sifat gas ideal monoatomik untuk SMA Kelas XI IPA.

Populasi dari penelitian ini merupakan keseluruhan subjek penelitian yang ingin penulis peroleh datanya. Sampel penelitian tiga siswa dari tiap kelas XI IPA SMA Negeri 3 Palangkaraya.

\section{HASIL}

Analisis dan Desain Produk

Kegiatan analisis dan desain produk merupakan tahap kegiatan untuk menerjemahkan data-data dari tahap penelitian sebelumnya (studi lapangan dan studi literatur) kedalam sebuah sistem. Tahap ini difokuskan pada merumuskan bentuk model dari media pembelajaran pokok bahasan konsep termodinamika dalam mesin kalor dan sifat-sifat gas ideal monoatomik dengan menganalisis beberapa data yang dapat dari studi lapangan dan studi literatur. 


\section{Pengembangan Materi}

Tahap pengembangan materi merupakan tahap merumuskan jenis materi yang akan diterapkan pada media pembelajaran Fisika pokok bahasan konsep termodinamika dalam mesin kalor dan sifat-sifat gas ideal monoatomik dan disesuaikan dengan kurikulum kelas XI IPA. Tahap ini difokuskan pada merumuskan isi materi dan menyesuaikan dengan jadwal kurikulum.

Pengembangan Produk

Pada tahap ini akan dijelaskan bagaimana tahapan pengembangan media pembelajaran Fisika pokok bahasan konsep termodinamika dalam mesin kalor dan sifat-sifat gas ideal monoatomik kelas XI IPA.

\section{Pengujian}

Pengujian kelayakan media pembelajaran Fisika pokok bahasan hukum konsep termodinamika dalam mesin kalor dan sifat-sifat gas ideal monoatomik, diuji secara keseluruhan dengan memperlihatkan dan memberikan angket kepada ahli materi dan ahli media untuk memperoleh informasi apakah media pembelajaran Fisika pokok bahasan konsep termodinamika dalam mesin kalor dan sifat-sifat gas ideal monoatomik layak atau tidak untuk digunakan.

Metode Pengembangan Sistem

Dalam membuat perangkat lunak penelitian ini penulis menggunakan metode waterfall. Menurut Budi Hermawan (2009) model Waterfall adalah sebuah metode pengembangan software yang bersifat sekuensial dan terdiri dari 5 tahap yang saling terkait dan mempengaruhi.

1. Analysis (analisis)

Tahap ini terdiri dari berbagai kegiatan yaitu :

a. Analisis kebutuhan terhadap bahan ajar berbasis animasi komputer sebagai salah satu media pembelajaran fisika. Analis ini digunakan sebagai dasar perlu tidaknya digunakan media pembelajaran fisika berbasis animasi komputer dalam kegiatan belajar mengajar. Analisis kebutuhan terhadap bahan ajar berbasis komputer dalam penelitian ini adalah program paket belajar fisika materi pokok bahasan.

b. Analisis kurikulum 2006 bidang studi fisika kelas XI 
c. IPA materi. Analisis

kurikulum digunakan sebagai dasar dalam pengembangan bahan ajar fisika berbasis komputer, yang mengacu pada kurikulum KTSP.

2. Perencanaan (Design)

Hasil analisis digunakan sebagai acuan dalam penyusunan suatu kerangka isi program media pembelajaran. Kerangka isi program untuk menggambarkan keseluruhan isi materi yang tercakup dalam bahan ajar tersebut lengkap dengan alur pembelajarannya beserta desain tampilan bahan ajar fisika berbasis komputer.

3. Produksi (Depelopment)

Kegiatan dilanjutkan dengan proses pembuatan bahan ajar fisika yang mengacu pada tahap Design.

4. Implementasi (Implementation) Media pembelajaran yang telah selesai dibuat diujicobakan kepada beberapa ahli perancangan media dan ahli bidang studi fisika. Pengujian media pembelajaran dilakukan dengan pengujian angket.
5. Evaluasi (Evaluation)

Proses akhir berdasarkan tahap hasil angket tahap implementasi, pada tahap ini software hasil penelitian yang diperbaiki dapat digunakan secara luas sebagai salah satu media belajar fisika.

\section{IMPLEMENTASI DAN ANALISIS}

\section{APLIKASI}

Form Menu Utama

Tampilan menu utama merupakan tampilan yang pertama kali muncul saat program dijalankan.

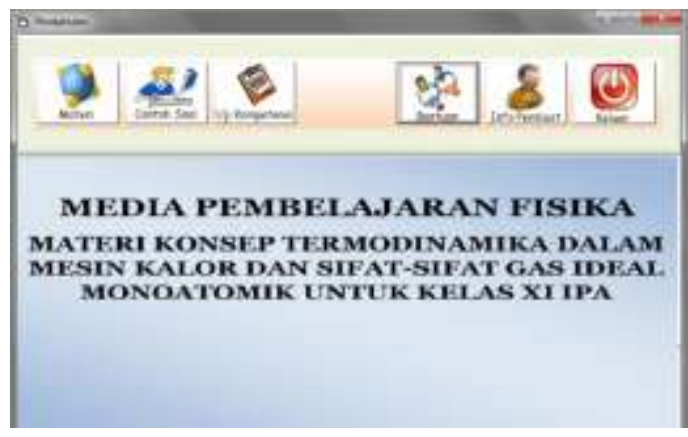

Gambar 2. Tampilan Menu Awal

Form materi

Menu materi berisi menu persamaan keadaan gas dan tekanan dan energi kinetik menurut teori kinetik gas. 


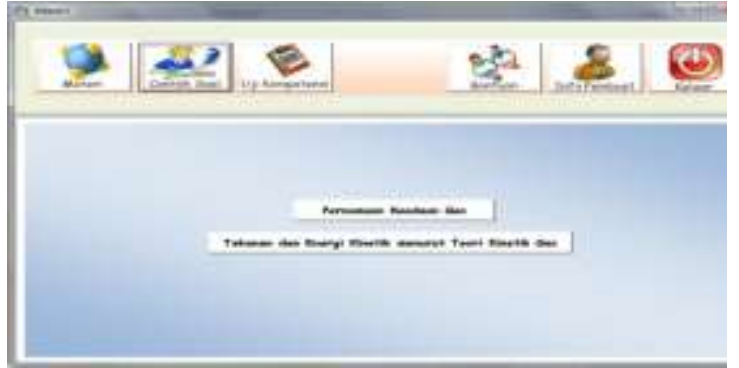

Gambar 3. Menu Materi

Selanjutnya akan tampil isi dari pengertian mol dan massa molekul, dapat dilihat pada gambar 4 .

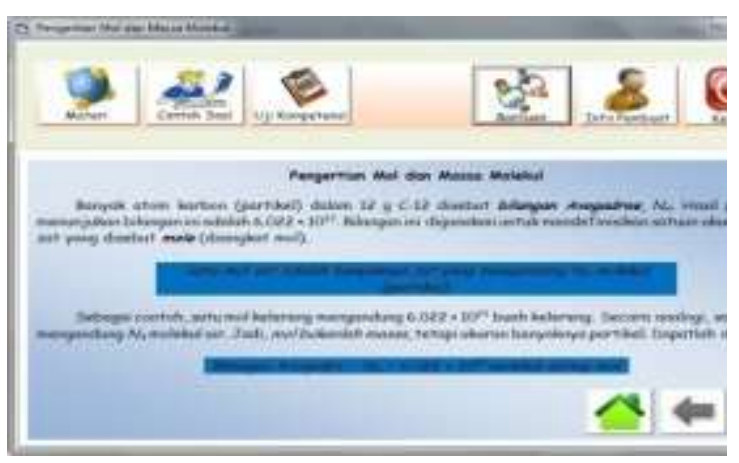

Gambar 4. Menu Materi Mol dan

Massa Molekul

Menu tekanan dan energi kinetik menurut teori kinetik gas dibagi menjadi empat materi, yaitu formulasi tekanan gas dalam wadah tertutup, energi kinetik rata-rata molekul gas, kelajuan efektif gas, dan teorema ekipartasi energi.

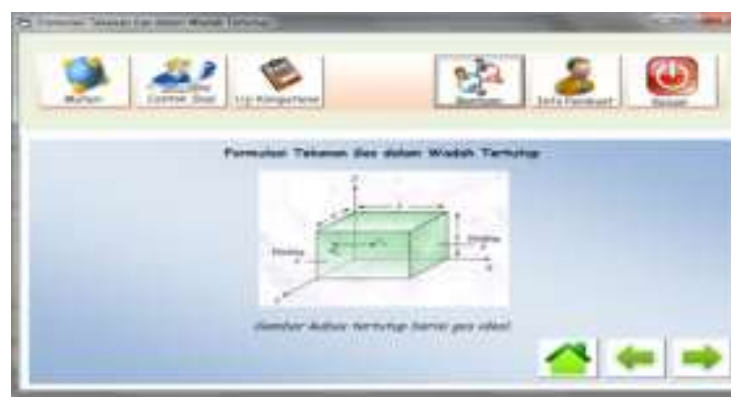

Gambar 5. Menu Formulasi Tekanan

Gas dalam Wadah Tertutup

Form Menu Contoh Soal

Pada menu soal akan dibagi contoh soal sesuai dengan materi masing-masing, seperti pada gambar 6 .

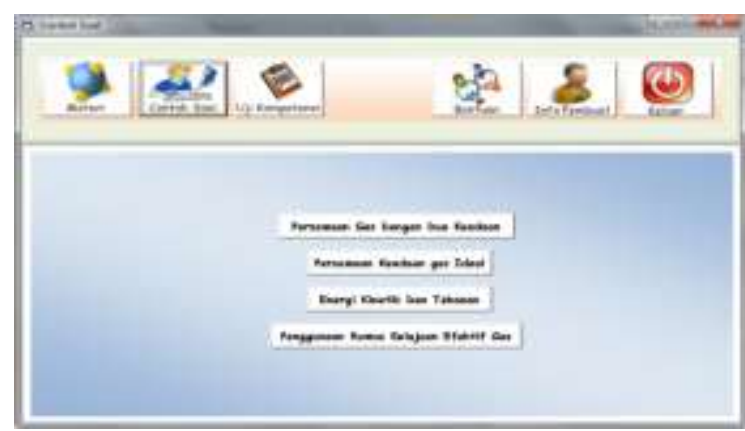

Gambar 6. Menu Contoh Soal

Begitu mengklik persamaan gas dengan dua keadaan maka akan tampil seperti gambar 7 .

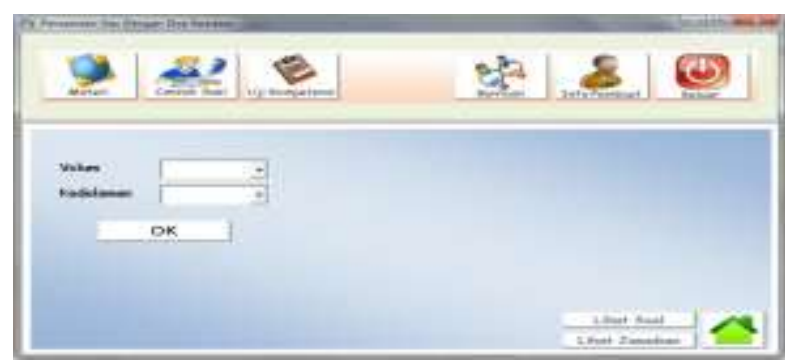

Gambar 7. Menu Contoh Soal Persamaan Gas dengan Dua Keadaan

Pada tampilan ini mengisi volume dan kedalam dulu lalu klik baru soal akan tertera, seperti gambar 8. 


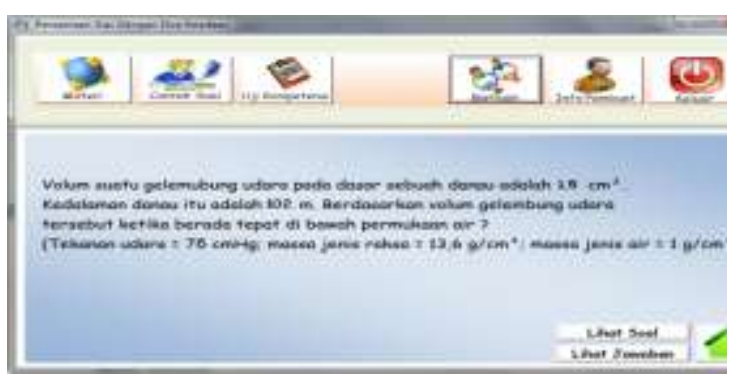

Gambar 8. Menu Contoh Soal

Pada tampilan ini soal akan tertera, jika tidak tau menjawabnya dapat di klik lihat jawaban, maka akan tampil jawaban dan cara mengerjakannya. Begitu juga pada soal-soal selanjutnya.

\section{Form Menu Uji Kompetensi}

Tampilan menu uji kompetensi berisi soal-soal dengan pilihan ganda, seperti pada gambar 9 .

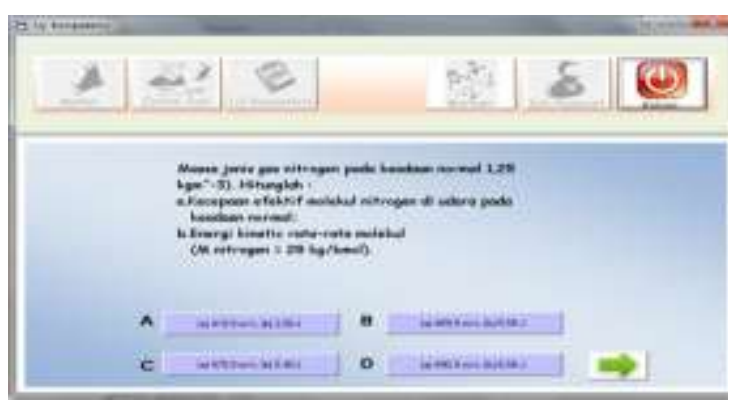

Gambar 9. Menu Uji Kompetensi

Apabila soal sudah selesai di jawabanya, maka akan tampil hasil dari jawaban yang skor, benar dan salah. Juga dapat dilihat soal yang salah gimana penjelasannya dan soal yang benar gimana juga penjelasannya.

Seperti pada gambar 10 .

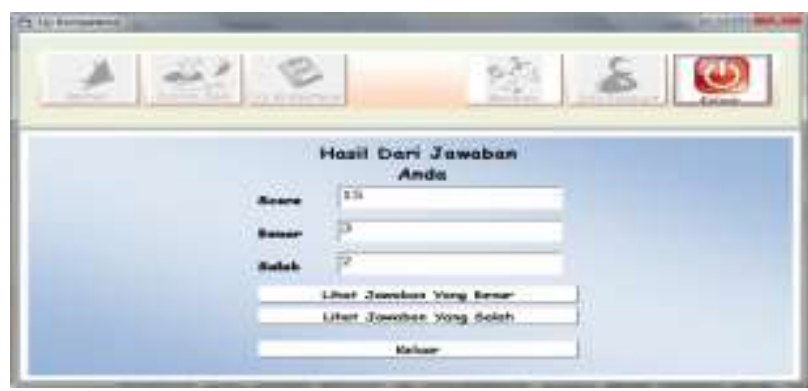

Gambar 10. Tampilan Menu Hasil Jawaban

Form Menu Bantuan

Tampilan menu bantuan berisi cara menggunakan program ini. Apabila ada kesulitan menggunakannya maka tinggal masuk ke menu bantuan. Dapat dilihat pada gambar 11 .

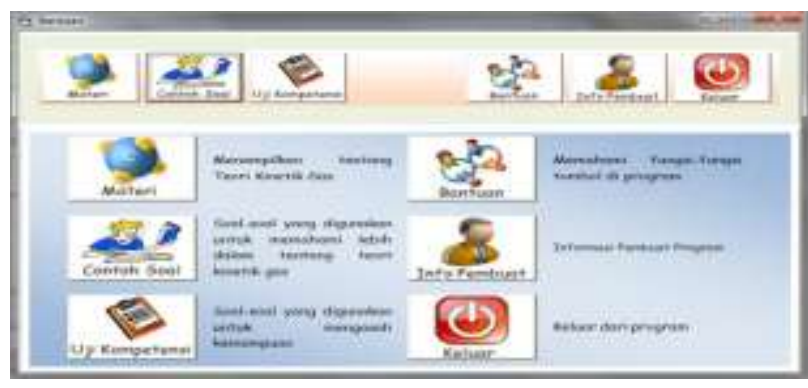

Gambar 11. Menu Bantuan

Pengujian

Program dianggap berhasil jika input, proses dan output aplikasi berjalan dengan baik sesuai dengan tujuan yang ingin dicapai. Untuk mengetahui kelebihan dan kekurangan program maka diperlukan suatu proses 
pengujian untuk menganalisis data berdasarkan angket yang telah dibuat. Maksud dari analisis data yaitu untuk mengetahui kelayakan media sebagai media pembelajaran fisika pokok bahasan konsep termodinamika dalam mesin kalor dan sifat-sifat gas ideal monoatomik. Pengujian angket media dilakukan dengan dua cara yaitu angket kepada beberapa ahli bidang studi fisika dan angket ahli perancangan media. Adapun hasil pengujian angket sebagai berikut:

1. Analisis Skor Angket Ahli Bidang Studi Fisika

Dari hasil pengujian menunjukan semua indikator mendapatkan nilai sangat tinggi, dengan nilai persentase variabel tampilan program sebesar 83,33 tergolong dalam katagori Baik, secara grafik terlihat seperti pada gambar 12.

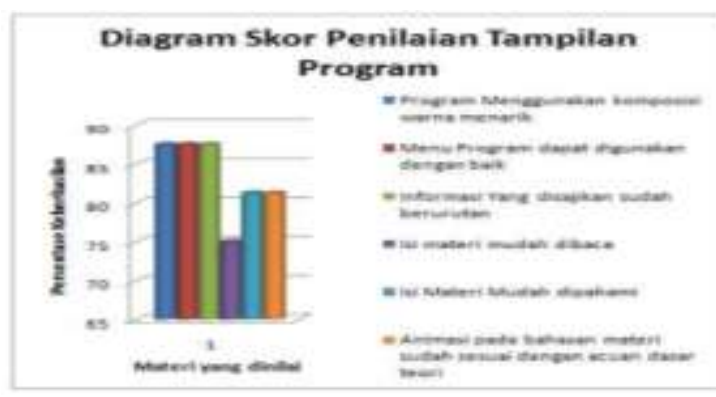

Gambar 12. Grafik Perolehan Skor

Penilaian Pada Aspek Tampilan

Program

2. Analisis Skor Angket Pakar Perancangan Media

Pengujian program

dilakukan dengan meminta responden mencoba program kemudian mendata tanggapan responden mengenai teknis program yang terdiri dari tampilan, desain dan rancangan program. Pengujian program ini dilakukan oleh dua orang responden yang terdiri dari kalangan dosen dan guru TI.

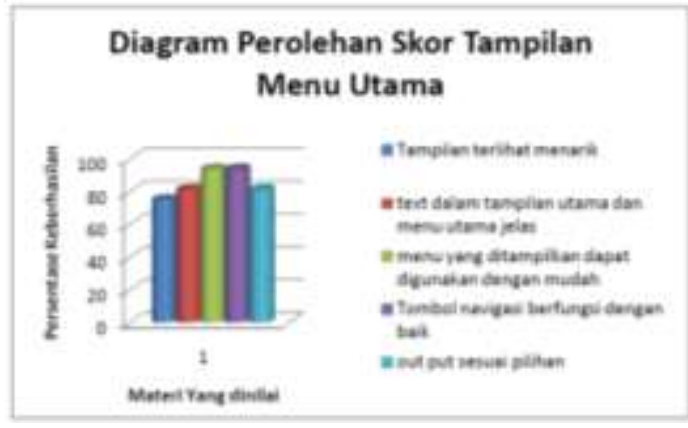

Gambar 13. Grafik Perolehan Skor Penilaian Pada Aspek Tampilan Menu Utama

\section{KESIMPULAN \\ Berdasarkan hasil penelitian yang telah dilakukan dapat diambil kesimpulan sebagai berikut:}


1. Telah dibuat aplikasi paket belajar fisika berbasis animasi komputer materi pokok bahasan termodinamika dalam mesin kalor dan sifat-sifat gas ideal monoatomik untuk SMA kelas XI IPA.

2. Program pembelajaran fisika berbasis animasi komputer materi pokok bahasan termodinamika dalam mesin kalor dan sifat-sifat gas ideal monoatomik untuk SMA kelas XI IPA, untuk kriteria tampilan program termasuk dalam kategori baik (83,33\%), kesesuaian program terhadap bahan ajar fisika pokok bahasan termodinamika dalam mesin kalor dan sifat-sifat gas ideal monoatomik dalam kategori baik $(85,42 \%)$. Dengan demikian program yang dikembangkan layak dijadikan sebagi media pembelajaran dan dapat dimanfaatkan dalam pembelajaran Fisika pokok bahasan termodinamika dalam mesin kalor dan sifat-sifat gas ideal monoatomik untuk SMA kelas XI IPA.

\section{SARAN}

Beberapa saran yang dapat
diberikan untuk pengembangan aplikasi ini adalah sebagai berikut:

1. Diharapkan aplikasi ini dapat digunakan di SMAN 3 Palangka Raya pada kelas XI IPA.

2. Aplikasi paket belajar fisika ini hanya mengajarkan materi pokok bahasan termodinamika dalam mesin kalor dan sifat-sifat gas ideal monoatomik sehingga dapat ditambahkan dengan materi lain.

3. Aplikasi paket belajar ini dapat dikembangkan berbasis android.

\section{DAFTAR PUSTAKA}

Arikunto, S. (2008). Dasar-Dasar Evaluasi Pendidikan. Jakarta: Bumi Aksara.

Arsyad, A. (2009). Media Pembelajaran. Jakarta: Rajawali. Asmani, M. J. (2011). Tips Efektif Pemanfaatan Teknologi Informasi dan Komunikasi dalam Dunia Pendidikan. Yogyakarta: Diva Press.

Aththibby, A. R. Perancangan Media

Pembelajaran Fisika Berbasis Animasi Komputer untuk Sekolah Menengah Atas Pokok Bahasan Hukum-Hukum 
Newton Tentang Gerak. Universitas

Ahmad Dahlan, Yogyakarta.

Kanginan, M. (2007). IPA FISIKA

Untuk SMA Kelas XI. Jakarta:

Erlangga.

Kristianto, A. W. Pengembangan

Media Pembelajaran E-Kamus

Komputer Teknologi Informasi dan

Komunikasi Menggunakan Visual

Basic 6.0 Kelas VII SMP Negeri 1

Welahan. Universitas Negeri,

Semarang.

Madcoms. (2008). Microsoft Visual

Basic 6.0 Untuk Pemula. Yogyakarta:

Andi.

Munir. (2010). Kurikulum Berbasis

Teknologi Informasi dan Komunikasi.

Bandung: Alfabeta.

Priandono, F. E., Astutik, S., \&

Wahyuni, S. (2012). Pengembangan

Media Audio-Visual Berbasis

Kontekstual dalam Pembelajaran

Fisika di SMA. Jurnal Pembelajaran

Fisika, 1-10.

Setiawan, A. (2007). Dasar-dasar

Pembelajaran Fisika. Bandung:

Universitas Pendidikan Indonesia.

Sugiono. (2009). Metode Penelitian

Pendidikan. Bandung: Alfabeta.

Triana, S. Pengaruh media kartu fisika terhadap prestasi belajar fisika pokok bahasan gaya pada siswa kelas VII SMPN 2 Pangkah, kabupaten tegal. Fakultas Keguruan Dan Ilmu Pedidikan, Program Studi Pendidikan Fisika. Universitas Ahmad Dahlan, Yogyakarta. 